\title{
Assessment of Growth and Yield Performance of Different Rice Genotypes at Baniyani (Kachankawal-6), Jhapa
}

\author{
Purnima Puri ${ }^{1 *}$, Santosh Marahatta ${ }^{2}$, Basanta Khanal ${ }^{1}$ and Rakshya \\ Poudel $^{1}$ \\ ${ }^{1}$ Department of Agriculture, Agriculture and Forestry University, Rampur, Chitwan, \\ Nepal \\ ${ }^{2}$ Department of Agronomy, Agriculture and Forestry University, Rampur, Chitwan, \\ Nepal
}

*Corresponding Author: Purnima Puri, Department of Agriculture, Agriculture and Forestry University, Rampur, Chitwan, Nepal.

Received: March 08, 2021

Published: March 29, 2021

(C) All rights are reserved by Purnima Puri., et al.

\section{Abstract}

The performance and productivity of rice crop is influenced by the genotype of the crop which is also location specific. A field experiment was conducted to recognize the suitable rice genotypes in terms of yield and performance at Baniyani, Jhapa. The experiment was carried out in RCBD design with three replication and eight treatments (genotypes). Two genotypes were used as check: Hardinath-1 for yield and earliness while Chaite-5 for quality whereas remaining six were pipeline genotypes namely: IR16L1636, IR98846-2-1-4-3, IR16L1831, IR15L1544, 1R16L1411 and IR-10N-118. There were 24 experimental units each of 9 m². Various data including Plant height $(\mathrm{cm})$, Number of tiller $\left(/ \mathrm{m}^{2}\right)$, Effective tiller $\left(/ \mathrm{m}^{2}\right)$, Panicle length $(\mathrm{cm})$, Number of grain per panicle, Sterility (\%), Thousand grain weight (gm), Seed length (cm), Seed diameter (cm), Grain yield (kg), Straw yield (kg), Harvest index (\%), Number of borer and smut infestation $\left(/ \mathrm{m}^{2}\right)$ and all results were significant at all parameters except for number of tiller at vegetative growth, panicle length (cm) and sterility (\%). Earliness was observed in Hardinath-1, plant height was high in IR16L1831, number of tiller was found more in Chaite-5, number of effective tiller was high in IR98846-2-1-4-3, panicle length was observed long in IR$10 \mathrm{~N}-118$, number of grain per panicle was more in Chaite-5, sterility was also high in Chaite-5, thousand grain weight of IR16L1831 was high, seed length was found high in IR16L1831 while seed diameter of IR16L1636 was more. Likewise, grain yield of Hardinath-1 was high, straw yield was high in IR16L1831, biological yield high in IR98846-2-1-4-3 and harvest index high in Hardinath-1. Keywords: Genotype; Check; Pipeline

\section{Introduction}

Rice (Oryza sativa L.) is one of the most important staple foods in the world as over half of the world's population depends on rice in their diet. The genus Oryza L. belongs under tribe Oryzae, subfamily Oryzoideae in the family Poaceae [1]. This genus is divided into four species complexes, they are: Oryza sativa, Oryza ridelyi, Oryza officials, and Oryza granulate [2]. Among these species of rice Oryza sativa is the most popular commercial species of rice
[3]. Rice is also principle food grain in Nepal followed by maize and wheat. Rice solely contributes to the $20.8 \%$ AGDP and is major cereal crop grown in Nepal [4]. The total area of Nepal is approximately 1.5 million ha with average productivity of 3.2 tha-1 producing 4.8 million tons of paddy rice [5]. Agriculture is the mainstay of Nepal's economy. It comprises one-third of the nation's Gross Domestic Product (GDP) and provides employment for two thirds of the population (Investment Board Nepal, 2016). 
Recognizing the need to build on success achieved so far to attain growth and equity, the country prepared Agriculture Development Strategy to replace the Agriculture Perspective Plans a long term perspective plan providing overall direction to ensuing development plans and aimed at fulfillment of basic needs focusing to secure food security for all by the end of $20^{\text {th }}$ year of implementation [4]. Similarly, Prime Minister Agriculture Modernization Project (PMAMP) was launched in 2016, with the objective of specialized production [4] and Jhapa district of province number 1 is the super zone of Rice under PMAMP.

Seed is the ultimate technology which encapsulate a package of disease resistance, quality and potential yield [6]. So, seed production and their location trial for suitability are very crucial. Effective agriculture research and extension is one of the key component in increasing agriculture productivity [7]. Because of complex and geographically diverse farming system, Nepalese farmers need portfolio of diverse crop genotypes with agro morphological and agronomical trait [8]. Similarly, most of the farmers rely on rain fed farming system. So, development of better rice genotypes for rain fed environment in Nepal has an important role for improving livelihood of farmer however, varietal development for rain fed environment was often neglected or rarely successful [9]. Likewise, in many cases information on source of seed could not be obtained from farmer [10], So, the actual purity and seed vigor is unknown which may not fit the destined location causing low productivity (Nation, 2018). Thus, the varietal trials in location specific area help to recommend the suitable genotype including both agro morphological and agronomical traits [11]. But research on varietal development should be focused on conserving local resources as well.

About three-fourths (74\%) of the paddy is produced in the flat lowland of the terai and the rest (26\%) in the hills and mountains (Pandey., et al. 2012). Jhapa is the potent district for rice production because of the suitability of agro-climatic. In Jhapa district rice can cultivate in three seasons i.e. winter, chaite and main season. Jhapa is the highest rice producing district of Nepal which has production of 338,000 metric ton with 87,500 ha and productivity of 3.86 [12]. Furthermore, irrigation facility in Jhapa district is facilitated by tube wells, solar energy or water canal. Despite of suitability of rice production in Jhapa, there exist large yield gap between attainable yield and farmer's yield. This may be due to lack of suitable genotypes, varietal improvement and suitable varietal recommendation by concerned agricultural authorities. There is also lack in the proper dissemination of the results from the varietal trials which has created the knowledge barrier for the rice farmers. Varietal trial will help in appropriate selection of genotype and help in increase of production and productivity of Jhapa district and as a whole of Nepal [13] because varietal trial help in calculating yield and all the yield parameters through which high yielding favorable genotypes can be selected. Similarly, selection of rice genotypes with wide adaptability over diverse farming environments is important, prior to varietal recommendation in order to achieve high rate of varietal adoption particularly in developing countries [14]. Rice yield must be increased by $3 \%$ annually for next two and half decades if the country aims to meet the domestic rice demand from own production [4]. So country should focus on self-sufficiency and release high yielding variety with location specific different varietal trials.

\section{Materials and Methods}

The experiment was conducted at Kachanakawal Rural Municipality. The site under Program Implementation Unit (PIU), rice Super-Zone of Prime Minister agriculture modernization project (PMAMP) lies in Baniyani, Kechankawal-6, Jhapa and from January 2020 to June 2020.The site was about $38 \mathrm{~km}$ south from Birtamod and $15 \mathrm{~km}$ southwest from district headquarter Bhadrapur. The research was conducted in Baniyani Bazar and geographically situated at $26^{\circ} 25^{\prime} 47.1^{\prime \prime} \mathrm{N}$ latitude and $88^{\circ} 02^{\prime} 15.3^{\prime \prime} \mathrm{E}$ with elevation of around 61 meter above sea level in the farmers field so that the farmers could be practically observed the demonstrated plots.

Climate of the experimental site is tropical sub-humid. Rice is the most appropriate according to the soil and climatic condition of this place. The temperature is the highest on average in June, at around $28.6^{\circ} \mathrm{C}$ on average, lowest during the January month of the year. Similarly, precipitation was highest during the month of July i.e. up to $723 \mathrm{~mm}$. Similarly, relative humidity is also high during month of July with about $90 \%$. Similarly, the soil pH was 4.7, organic matter was $4.3 \%$, nitrogen $0.17 \%$, available phosphorous was found to be $29.07 \mathrm{kgha}^{-1}$ and available potash was found to be $102 \mathrm{kgha}^{-1}$. 


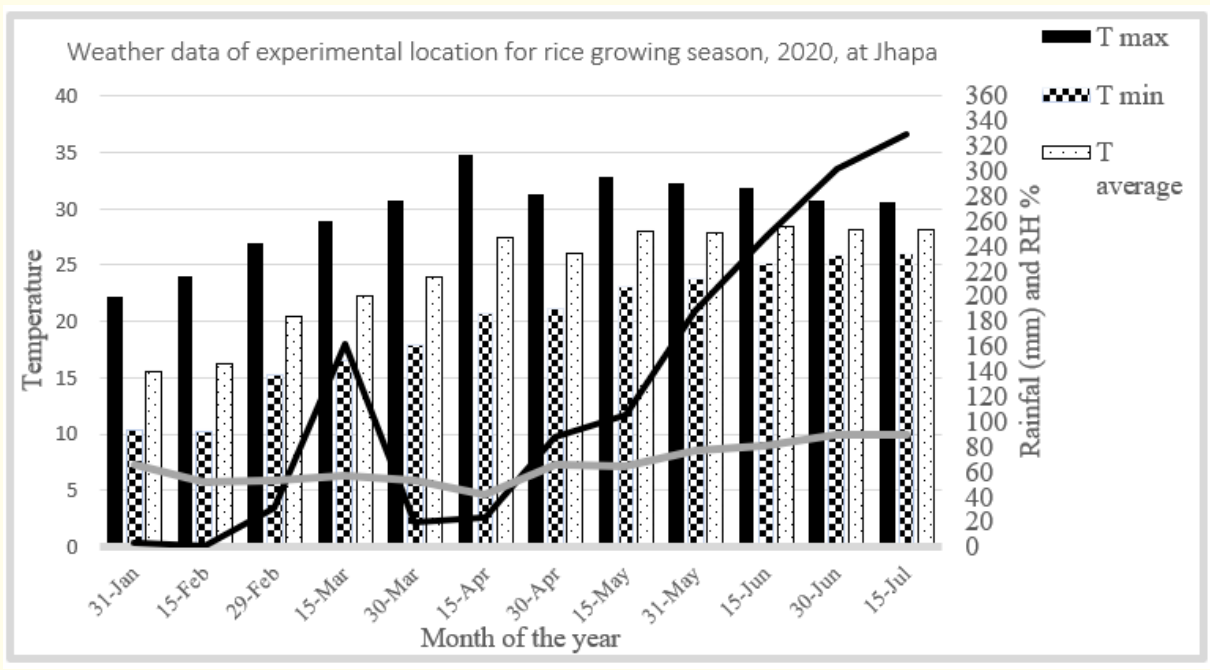

Figure 1: Weather data of experimental location for rice growing season, 2020, at Jhapa. Source: worldweatheronline.com.

\begin{tabular}{|l|c|}
\hline Nutrient on soil & Clay loam \\
\hline Soil type & 4.7 \\
\hline Soil pH & 4.3 \\
\hline Organic matter (\%) & 0.17 \\
\hline Nitrogen (\%) & 29.07 \\
\hline Available phosphorous (kgha-1) & 102 \\
\hline Available potash $\left(\mathrm{kgha}^{-1}\right)$ &
\end{tabular}

Table 1: Physico-chemical characteristics of experimental soil.

In the experiment, eight genotypes were used as different treatments and with three replication. Total number of plot was 24 and individual plot size was $3 \mathrm{~m}^{*} 3 \mathrm{~m}\left(9 \mathrm{~m}^{2}\right) .27$ days old seedlings were used for transplantation. Three seedlings per hill were transplanted in the spacing of $20 \mathrm{~cm} * 20 \mathrm{~cm}$. The chemical fertilizer was applied at the rate of 100:40:30 kg/ha. The whole dose of phosphorus and potash and $50 \%$ dose of nitrogen were applied as basal dose and remaining dose of nitrogen was top dressed during tillering and panicle initiation. The crop was given irrigation during crop establishment, tillering and panicle initiation stage. Data were recorded and analyzed during data analysis. Microsoft excel and Rstudio was used for data analysis.

\section{Result and Discussion}

The result obtained during research were analyzed and presented in the section with the help of tables and figures wherever necessary. The results obtained are discussed with possible results and literature support.

Phenological parameter i.e. days to flowering

From the result obtained from research, we got to know that late flowering genotype was Chaite- 5 with 111 DAS which is statistically at par with IR16L1831 with 110 DAS. Similarly IR15L1544 flower at 109 DAS which is statistically at par with IR16L1831, 110 DAS and IR98846-2-1-4-3, 108 DAS. Likewise, IR16L1636 flowers at 106 DAS which is statistically at par with IR16L1411. Early flowering genotype was Hardinath-1 with 102 DAS followed by IR-10N-118 with 104 DAS. From this data; we can say that early flowering genotype is Hardinath-1 and late flowering genotype is Chaite-5.

Oladosu., et al. [15], also revealed highly significant difference $(p<0.001)$ among different genotypes of rice for all the characters studies including Phenological character except for panicle length and 100-grain weight. Similarly, (Jing and Dai, 2020) stated that phenology of genotypes varied strongly across environment. 


\begin{tabular}{|l|c|}
\hline Treatments & Day to flowering (DAS) \\
\hline 1.IR16L1636 & $106^{\mathrm{e}}$ \\
\hline 2.IR98846-2-1-4-3 & $108^{\mathrm{cd}}$ \\
\hline 3.IR16L1831 & $110^{\mathrm{ab}}$ \\
\hline 4.IR15L1544 & $109^{\mathrm{bc}}$ \\
\hline 5.IR16L1411 & $107^{\mathrm{de}}$ \\
\hline 6.IR-10N-118 & $104^{\mathrm{f}}$ \\
\hline 7.Chaite-5 & $111^{\mathrm{a}}$ \\
\hline 8.Hardinath-1 & $102^{\mathrm{g}}$ \\
\hline SEm \pm () & 0.62 \\
\hline LSD= (0.05) & 1.30 \\
\hline CV, \% & 0.70 \\
\hline F value & $* * *$ \\
\hline Grand mean & 107 \\
\hline
\end{tabular}

Table 2: Days to $50 \%$ flowering of rice genotypes during the spring season of 2020 at Jhapa, Nepal.

Note: DAS, days after Sowing, SEm, standard error of mean; LSD, least significance difference, $\mathrm{CV}$, coefficient of variation, ${ }^{* * *}$ represent significant at $0.1 \%$ level. Treatment mean followed by same letter(s) are non-significance difference on Duncan multiple range test at 0.05 level of significance.

\section{Biometrical observation}

\section{Plant height}

Plant height was found significant at all growth stage.

At 15DAT, Plant height of IR98846-2-1-4-3 was superior with $11.84 \mathrm{~cm}$ which was statistically at par with IR16L1831 (11.67CM), IR15L1544 (11.69), IR16L1411 (11.12). Similarly, Hardinath-1 was with small plant height $(9.96 \mathrm{~cm})$ which was statistically at par with Chaite-5 (10.11cm), IR16L1636 (10.13cm) and IR-10N-118 $(10.15 \mathrm{~cm})$.

At 30 DAT, Plant height of IR98846-2-1-4-3 was superior with $24.85 \mathrm{~cm}$ which was statistically at par with IR16L1831 (24.82 $\mathrm{cm})$, IR16L1411 (23.98 cm) and Chaite-5 (23.13 cm). Moderate plant height of IR-10N-118 (22.67 cm). Similarly, IR16L1636 was with small plant height $(20.86 \mathrm{~cm})$ which was statistically at par with Hardinath-1 (21.41 cm), IR15L1544 (22.15 cm).

At 45 DAT, genotype IR16L1831 was superior in plant height with $44.31 \mathrm{~cm}$ followed by IR98846-2-1-4-3 (41.73 cm) which was statistically at par with IR16L1411 $(41.48 \mathrm{~cm})$ and Chaite-5 (40.86 $\mathrm{cm})$. Height of IR16L1636 was smallest with plant height $65.15 \mathrm{~cm}$ which was statistically at par with Hardinath-1 (38.86).

At 60 DAT, IR16L1831 has superior plant height $(73.57 \mathrm{~cm})$ followed by IR98846-2-1-4-3 $(69.81 \mathrm{~cm})$ which was statistically at par with IR16L1411 (70.99 cm), IR15L1544 (68.49 cm) and Chaite-5 (69.19 cm). Small plant height was observed in IR16L1636 (65.15 $\mathrm{cm})$ which is statistically at par with Hardinath-1 $(66.80 \mathrm{~cm})$ and IR-10N-118 (67.46 cm).

At harvest, superior plant height was observed in IR16L1831 $(104.99 \mathrm{~cm})$ which was statistically was at par with IR98846-2-14-3 $(101.35 \mathrm{~cm})$ followed by IR15L1544 $(99.80 \mathrm{~cm})$ which was statistically at par with IR16L1636 $(97.19 \mathrm{~cm})$, IR16L1411 $(97.46 \mathrm{~cm})$ and Chaite-5 $(96.60 \mathrm{~cm})$. Smallest plant height was observed in IR-10N-118 (93.54 cm) which was statistically at par with Hardinath-1 $(95.1 \mathrm{~cm})$.

Adhikari., et al. [16] concluded the existence of significant difference for plant height, days to flowering, maturity, thousand grain weight and grain yield among difference genotypes of rice used in their trial (Table 3).

Number of tiller per $\mathbf{m}^{2}$

The number of tiller was found non-significant at every growth stage. However, number of tiller was found to be high in Chaite-5 followed by Hardinath-1, IR16L1411, IR-10N-118, IR98846-2-1-43, IR15L1544, IR16L1636 and IR16L1631 respectively.

At harvest, number of tiller was found highest in Chaite- 5 and lowest in IR16L1831.

Poudel., et al. [17] also found the significant difference among all the parameters under study except for number of tillers among different pipeline genotypes of rice. 


\begin{tabular}{|c|c|c|c|c|c|}
\hline \multirow{2}{*}{ Treatments } & \multicolumn{5}{|c|}{ Plant Height (cm) } \\
\hline & 15DAT & 30DAT & 45DAT & 60DAT & At harvest \\
\hline 1.IR16L1636 & $10.13^{\mathrm{bc}}$ & $20.86^{\mathrm{d}}$ & $37.61^{\mathrm{e}}$ & $65.15^{\mathrm{e}}$ & $97.19^{\mathrm{bcd}}$ \\
\hline $\begin{array}{l}\text { 2.IR98846-2- } \\
1-4-3\end{array}$ & $11.84^{\mathrm{a}}$ & $24.85^{\mathrm{a}}$ & $41.73^{b}$ & $69.81^{b}$ & $101.35^{\mathrm{ab}}$ \\
\hline 3.IR16L1831 & $11.67^{\mathrm{a}}$ & $24.82^{\mathrm{a}}$ & $44.31^{\mathrm{a}}$ & $73.57^{a}$ & $104.99^{a}$ \\
\hline 4.IR15L1544 & $11.69^{\mathrm{a}}$ & $22.15^{\mathrm{cd}}$ & $39.22^{\text {cde }}$ & $68.49^{\mathrm{bcd}}$ & $99.807^{\mathrm{bc}}$ \\
\hline 5.IR16L1411 & $11.12^{\mathrm{ab}}$ & $23.98^{\mathrm{ab}}$ & $41.48^{\mathrm{bc}}$ & $70.99^{b}$ & $97.46^{\text {bcd }}$ \\
\hline 6.IR-10N-118 & $10.15^{\mathrm{bc}}$ & $22.67^{\mathrm{bc}}$ & $39.64 b^{\text {cde }}$ & $67.46^{\text {cde }}$ & $93.54^{\mathrm{d}}$ \\
\hline 7.Chaite-5 & $10.11^{\mathrm{bc}}$ & $23.13^{\mathrm{abc}}$ & $40.86^{\mathrm{bcd}}$ & $69.19^{\mathrm{bcd}}$ & $96.60^{\mathrm{bcd}}$ \\
\hline 8.Hardinath-1 & $9.69^{c}$ & $21.41^{\mathrm{cd}}$ & $38.86^{\text {de }}$ & $66.80^{\text {de }}$ & $95.1^{\mathrm{cd}}$ \\
\hline $\operatorname{SEm}( \pm)$ & 0.20 & 0.31 & 0.46 & 0.62 & 0.92 \\
\hline$L S D=(0.05)$ & 1.16 & 1.63 & 2.5 & 2.56 & 5.10 \\
\hline $\mathrm{CV}, \%$ & 6.12 & 4.03 & 3.53 & 2.12 & 2.97 \\
\hline F value & $* *$ & $* *$ & $* *$ & $* * *$ & $* *$ \\
\hline Grand mean & 10.80 & 23.10 & 40.46 & 68.93 & 98.26 \\
\hline
\end{tabular}

Table 3: Plant height $(\mathrm{cm})$ of different rice genotypes during the spring season of 2020 at Jhapa, Nepal

Note: DAT, days after Transplantation, SEm, standard error of mean; LSD, least significance difference, CV, coefficient of variation, *** represent significant at $0.1 \%$ level, ${ }^{* *}$ represent significant at $1 \%$ level. Treatment mean followed by same letter(s) are non-significance difference on Duncan multiple range test at 0.05 level of significance.

\begin{tabular}{|l|c|c|c|c|c|}
\hline Treatments & \multicolumn{5}{|c|}{ Tiller number/m } \\
\hline & 15DAT & 30DAT & 45DAT & 60DAT & At harvest \\
\hline 1. IR16L1636 & 173.33 & 325 & 358.3 & 366.7 & 331.67 \\
\hline 2.IR98846-2-1-4-3 & 151.67 & 310 & 368.3 & 381.7 & 341.67 \\
\hline 3.IR16L1831 & 155 & 305 & 370 & 381.7 & 301.67 \\
\hline 4.IR15L1544 & 131.67 & 301.7 & 368.3 & 380 & 336.67 \\
\hline 5.IR16L1411 & 163.33 & 325 & 383.3 & 390 & 353.33 \\
\hline 6.IR-10N-118 & 146.67 & 310 & 395 & 390 & 351.67 \\
\hline 7.Chaite-5 & 156.67 & 326.67 & 400 & 401.7 & 361.67 \\
\hline 8.Hardinath-1 & 146.67 & 325 & 393.33 & 395 & 361.67 \\
\hline SEm ( $)$ & 3.91 & 5.95 & 6.19 & 4.20 & 5.71 \\
\hline LSD= (0.05) & NS & NS & NS & NS & NS \\
\hline CV, \% & 11.45 & 10.69 & 8.61 & 5.42 & 6.67 \\
F value & NS & NS & NS & NS & NS \\
\hline Grand mean & 153.33 & 316.04 & 379.58 & 385.83 & 342.50 \\
\hline
\end{tabular}

Table 4: Number of tiller per meter square of different rice genotypes during the spring season of 2020 at Jhapa, Nepal.

Note: DAT, days after Transplantation, SEm, standard error of mean; LSD, least significance difference, CV, coefficient of variation, NS, Non-significant. Treatment mean followed by same letter(s) are non-significance difference on Duncan multiple range test at 0.05 level of significance. 


\section{Yield attributing characters of rice}

For yield attributing character, data of effective tiller $/ \mathrm{m}^{2}$, panicle length, Grain per panicle, Sterility, Thousand grain weight, Seed length and seed diameter were taken. Among these parameters, Panicle length and Sterility were non-significant while other remaining parameters were highly significant at $0.1 \%$ level of significance.

Number of effective tiller per $\mathbf{m}^{2}$

The analyzed data presented in the table shows that effective tiller for different genotypes of rice were significant at $0.1 \%$ level of significance Among the eight genotypes of rice, number of effective tiller per $\mathrm{m}^{2}$ was found to be high of IR98846-2-1-4-3 (186.11/ $\left.\mathrm{m}^{2}\right)$ which was significantly at par with Hardinath-1 $\left(256.67 / \mathrm{m}^{2}\right)$ and IR16L1411 (245.56/ $\left.\mathrm{m}^{2}\right)$. Similarly, IR-10N-118 had $232.23 / \mathrm{m}^{2}$ effective tiller followed by IR15L1544 $\left(226.12 / \mathrm{m}^{2}\right)$ which was statistically at par with Chaite-5 $\left(221.11 / \mathrm{m}^{2}\right)$. Lowest number of effective tiller per $\mathrm{m}^{2}$ was observed in IR16L1636 $\left(186.11 / \mathrm{m}^{2}\right)$ which was statistically at par with IR16L1831 $\left(226.12 / \mathrm{m}^{2}\right)$.

Shahidullah., et al. [18], also observed variation in effective tillering dynamics among different genotypes of rice.

\section{Panicle length}

The variation in panicle length was not significantly different among various genotypes of rice.

However, longer panicle length was observed in IR-10N-118 $(23 \mathrm{~cm})$ followed by Chaite-5 $(22.19 \mathrm{~cm})$, IR16L1831 $(21.62 \mathrm{~cm})$, IR19L1636 (21.61 cm), IR98846-2-1-4-1 (21.11 cm), IR15L1544 $(21.43 \mathrm{~cm})$, IR16L1411 $(21.43 \mathrm{~cm})$ and Hardinath-1 $(21.18 \mathrm{~cm})$ respectively.

Oladosu., et al. (2018) finds the non significant difference for the panicle length among the genotypes of rice.

Number of grain per panicle

Statistically, grain per panicle was high on Chaite-5 (212.21) followed by IR16L1411 (138.13) which was statistically at par with Hardinath-1 (132.08), IR-10N-118 (128.43) and IR98846-2-1-43 (108.48). Similarly, least number of grains per panicle was observed in IR16L1636 (95.15), which were statistically in par with IR15L1544 (96.52) and IR16L1831 (99.78).
Saif-Or-Raisheed., et al. [19] finds highly significant difference of grain per panicle among different genotypes of rice during their research.

\section{Sterility (\%)}

The analyzed data presented in the table shows that panicle sterility for different genotypes of rice were not significant at i.e. (P > 0.05). However, maximum number of sterile grain was observed in Chaite-5 (28.57), followed by IR-10N-118 (26.51), IR16L1636 (25), IR16L1831 (22.58), IR98846-2-1-4-3 (21.64), IR15L1544 (21.15) and Hardinath-1 (20.9) respectively.

\section{Thousand grain weight (gm)}

Maximum thousand grain weight was observed in IR16L1831 (30.85 gm) which was statistically in par with IR15L1544 (29.39 gm) while least thousand grain weight was observed in Chaite-5 (16.94 gm). While remaining five genotypes were statistically in par with similar observation.

Howladar., et al. [20] suggested the significant difference in thousand grain weight due to genetic makeup.

Grain length ( $\mathrm{mm})$

The analysis of variance (Appendix 7) showed that the different genotypes of rice has significant effect $(\mathrm{P}<0.001)$ on grain length.

Grain length was found superior in genotype IR16L1831 (11.08 $\mathrm{mm}$ ), followed by IR16L1636 (10.40 mm), IR98846-2-1-4-3 (10.13 $\mathrm{mm})$, IR15L1544 (10.10 mm), IR16L1411 (9.73 mm), Hardinath-1 (8.86 mm), IR-10N-118 (8.52 $\mathrm{mm})$ and Chaite-5 (7.19 $\mathrm{mm})$ respectively. Here, treatment 2 and treatment 4 were statistically at par.

(Rao, 2005) [21] suggest that seed setting, seed lechate conductivity, potential seed longevity, \% seed germination and proportion of seed discoloration were influenced by environmental effects than genotypic effects while yield, panicle number, seed weight and high density of grain were influenced by genotypic effect than environmental effect.

\section{Grain diameter (mm)}

The analysis of variance (Appendix 7) showed that the different genotypes of rice has significant effect $(\mathrm{P}<0.001)$ on grain diameter. 
Grain diameter of IR16L1636 was maximum with value $2.41 \mathrm{~mm}$ followed by IR98846-2-1-4-3 (2.17 $\mathrm{mm})$ which was statistically at par with Chaite-5 (2.12 mm). Similarly, least seed diameter was observed in IR-10N-118 (2.10 mm) which was statistically at par with IR16L1831 (2.11mm), IR15L1544 (2.11 mm) and IR16L1411 $(2.11 \mathrm{~mm})$. While Hardinath-1 noted moderate seed diameter with value $2.12 \mathrm{~mm}$.

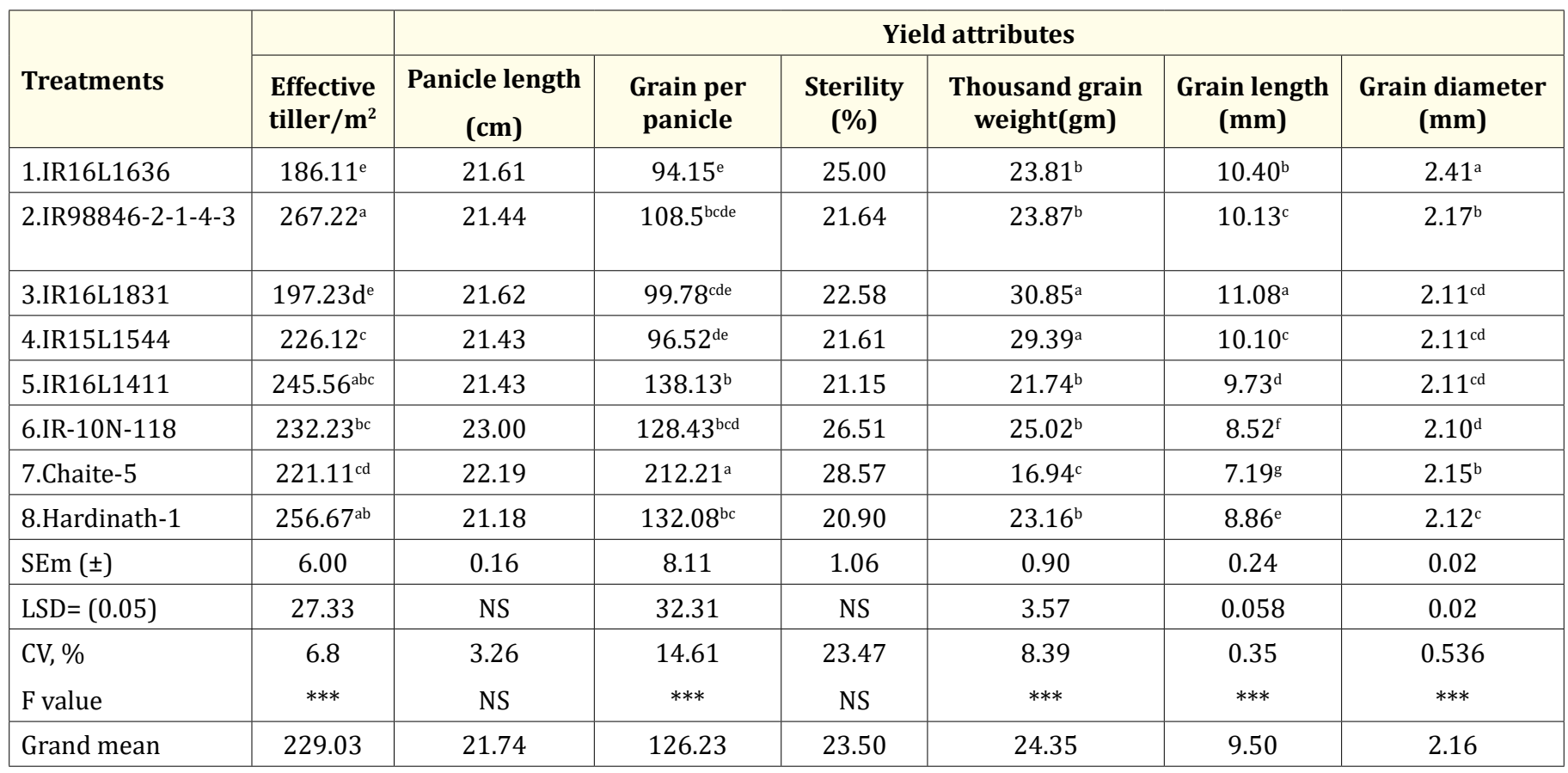

Table 5: Yield attributes of different rice genotypes during the spring season of 2020 at Jhapa, Nepal.

Note: SEm, standard error of mean; LSD, least significance difference, CV, coefficient of variation. Treatment mean followed by same letter(s) are non-significance difference on Duncan multiple range test at 0.05 level of significance.

\section{Yield parameters of rice}

The analyzed data tables below show that yield parameter of different genotypes of rice are significant at different level of significance. Grain yield is significant at $0.1 \%$ level of significance while straw yield and biological yield are significant at 5\% level of significance. Similarly harvest index is significant at $1 \%$ level of significance.

Grain yield

Statistically, grain yield was found high on Hardinath-1 (6214.71 $\mathrm{kg} / \mathrm{ha}$ ). Similarly, higher yield was followed by IR98846-2-1-4-3 (5569.34 kg/ha) which was statistically at par with IR16L1411 (5238.39 kg/ha) and IR15L1544 (5238.39 kg/ha). Grain yield of Chaite-5 was $5018.76 \mathrm{~kg} / \mathrm{ha}$ which was statistically at par with
IR16L1831 (4893.53 kg/ha). Least grain yield was observed in IR$10 \mathrm{~N}-118$ (4620.25) which was statistically at par with IR16L1636 (4591.64).

Jadhav., et al. [22] suggested $\mathrm{G}^{*} \mathrm{E}$ interaction effect showed that the genotypes responded differently to the variation in environmental condition or seasonal fluctuation and explained that most of the traits were contributed mainly by genotype followed by environment and their interaction. Hardinath-1 is high yielding spring rice genotype Subedi., et al. [23].

\section{Straw yield}

Highest straw weight was observed in IR16L1831 (5856.67 kg/ ha), which was statistically at par with, IR98846-2-1-4-3 (5765.30 kg/ha), IR15L1544 (5752.78 kg/ha), Chaite-5 (5303.49 kg/ha), 
IR16L1411 (4714.19 kg/ha) and IR-10N-118 (4920.26). Least straw weight was observed in IR16L1636 (3938.40 kg/ha) which was statistically at par with Hardinath-1 (4237.05 kg/ha).

Straw yield, biomass partitioning indices and fiber composition varied significantly to rice genotypes Matías., et al. [24].

\section{Biological Yield}

Maximum biological yield was observed in IR98846-2-1-4-3 (11334.64 kg/ha) while minimum was observed in IR16L1636 (8530.40 kg/ha) numerically.
Hossain., et al. (2014) found that, the variation in biological yield was also found due to variation in grain and straw yield.

\section{Harvest index}

Harvest index of Hardinath-1 was found superior (59.65\%). After Hardinath-1, harvest index of IR1611636 (53.92\%) was superior which was statistically at par with IR16L1411 (53.11\%), IR988462-1-4-3 (49.17\%), Chaite-5 (48.67\%) and IR-10N-118 (48.64\%). Least harvest index was observed in IR16L1831 (45.55\%) which was statistically at par with IR15L1544 (46.80\%).

\begin{tabular}{|l|c|c|c|c|}
\hline \multirow{2}{*}{ Treatments } & & \multicolumn{3}{|c|}{ Yield } \\
\cline { 2 - 5 } & Grain Yield (kg/ha) & Straw Yield (kg/ha) & Biological yield (kg/ha) & Harvest Index (\%) \\
\hline 1.IR16L1636 & $4591.64^{\mathrm{d}}$ & $3938.40^{\mathrm{c}}$ & 8530.04 & $53.92^{\mathrm{b}}$ \\
\hline 2.IR98846-2-1-4-3 & $5569.34^{\mathrm{b}}$ & $5765.30^{\mathrm{a}}$ & 11334.64 & $49.17^{\mathrm{bc}}$ \\
\hline 3.IR16L1831 & $4893.53^{\mathrm{cd}}$ & $5856.67^{\mathrm{a}}$ & 10750.19 & $45.55^{\mathrm{c}}$ \\
\hline 4.IR15L1544 & $5057.5^{\mathrm{bcd}}$ & $5752.78^{\mathrm{a}}$ & 10810.29 & $46.80^{\mathrm{c}}$ \\
\hline 5.IR16L1411 & $5238.39^{\mathrm{bc}}$ & $4714.19^{\mathrm{abc}}$ & 9952.590 & $53.11^{\mathrm{b}}$ \\
\hline 6.IR-10N-118 & $4620.25^{\mathrm{d}}$ & $4920.26^{\mathrm{abc}}$ & 9540.52 & $48.64^{\mathrm{bc}}$ \\
\hline 7.Chaite-5 & $5018.76^{\mathrm{cd}}$ & $5303.49^{\mathrm{ab}}$ & 10322.25 & $48.67^{\mathrm{bc}}$ \\
\hline 8.Hardinath-1 & $6214.71^{\mathrm{a}}$ & $4237.05^{\mathrm{bc}}$ & 10897.22 & $59.65^{\mathrm{a}}$ \\
\hline SEm ( \pm ) & 112.40 & 182.12 & 224.45 & 1.02 \\
\hline LSD= (0.05) & 527.09 & 1262.92 & NS & 5.377 \\
\hline CV, \% & 5.84 & 14.24 & 8.4 & 6.05 \\
F value & $* * *$ & 10211.54 & 50.69 \\
\hline Grand mean & 5150.52 & 5061.02 & & \\
\hline
\end{tabular}

Table 6: Grain yield, straw yield, biological yield and harvest index of different rice genotypes during the spring season of 2020 at Jhapa, Nepal.

Note: SEm, standard error of mean; LSD, least significance difference, CV, coefficient of variation, ${ }^{* * *}, 0.1 \%$ level of significance, ${ }^{* *}, 1 \%$ level of significance, *, 5\% level of significance. Treatment mean followed by same letter(s) are non-significance difference on Duncan multiple range test at 0.05 level of significance.

Rice stem borer and false smut infestation as influenced by different genotypes of rice

The analysis of variance (Appendix 9) showed that intensity of borer and false smut infestation is significant for different genotypes of Rice. Both stem borer and false smut infestation were significant with respect to genotypes. Borer infestation was found very high on Chaite-5, which was statistically at par withIR16L1831 and
IR15L1544. The stem borer (white head) was very low in Hardinath-1 which was statistically at par with IR16L1636 and IR988462-1-4-3. Similarly, false smut count was very high in IR16L1831 and null in Chaite-5 and Hardinath-1. Shafique., et al. [24] revealed that larval damage varied significantly with genotypes of rice. Dwivedi., et al. [25] observed significant difference for resistance to false smut disease among genotypes [26-32]. 


\begin{tabular}{|l|c|c|}
\hline \multirow{2}{*}{ Treatments } & \multicolumn{2}{|c|}{ Borer and Smut infestation } \\
\cline { 2 - 3 } & $\begin{array}{c}\text { No. of white head/ } \\
\mathbf{m}^{2}\end{array}$ & $\begin{array}{c}\text { No. of False smut/ } \\
\mathbf{m}^{2}\end{array}$ \\
\hline 1.IR16L1636 & $(15) 3.43^{\mathrm{bc}}$ & $(5.66) 2.35^{\mathrm{ab}}$ \\
\hline 2.IR98846-2-1-4-3 & $(9.47) 2.84^{\mathrm{bc}}$ & $(8.33) 2.90^{\mathrm{ab}}$ \\
\hline 3.IR16L1831 & $(18.9) 4.36^{\mathrm{ab}}$ & $(12.2) 3.40^{\mathrm{a}}$ \\
\hline 4.IR15L1544 & $(17.75) 4.17^{\mathrm{ab}}$ & $(11.67) 3.16^{\mathrm{ab}}$ \\
\hline 5.IR16L1411 & $(17.76) 4.98^{\mathrm{b}}$ & $(4.43) 2.13^{\mathrm{abc}}$ \\
\hline 6.IR-10N-118 & $(2.23) 1.63^{\mathrm{c}}$ & $(3.33) 1.92^{\mathrm{bc}}$ \\
\hline 7.Chaite-5 & $(41.12) 6.44^{\mathrm{a}}$ & $(0.00) 0.71^{\mathrm{c}}$ \\
\hline 8.Hardinath-1 & $(2.77) 1.67^{\mathrm{c}}$ & $(0.00) 0.71^{\mathrm{c}}$ \\
\hline SEm $( \pm)$ & 0.37 & 0.25 \\
\hline LSD= $(0.05)$ & 2.33 & 1.47 \\
\hline CV, \% & 37.30 & 38.75 \\
\hline F vale & $*$ & $* *$ \\
\hline Grand mean & 3.58 & 2.16 \\
\hline
\end{tabular}

Table 7: Borer and false smut infestation among the different rice genotypes during the spring season of 2020 at Jhapa, Nepal.

Note: SEm, standard error of mean; LSD, least significance difference, $\mathrm{CV}$, coefficient of variation, *, $5 \%$ level of significance, ** $1 \%$ level of significance. Treatment mean followed by same letter(s) are non-significance difference on Duncan multiple range test at 0.05 level of significance.

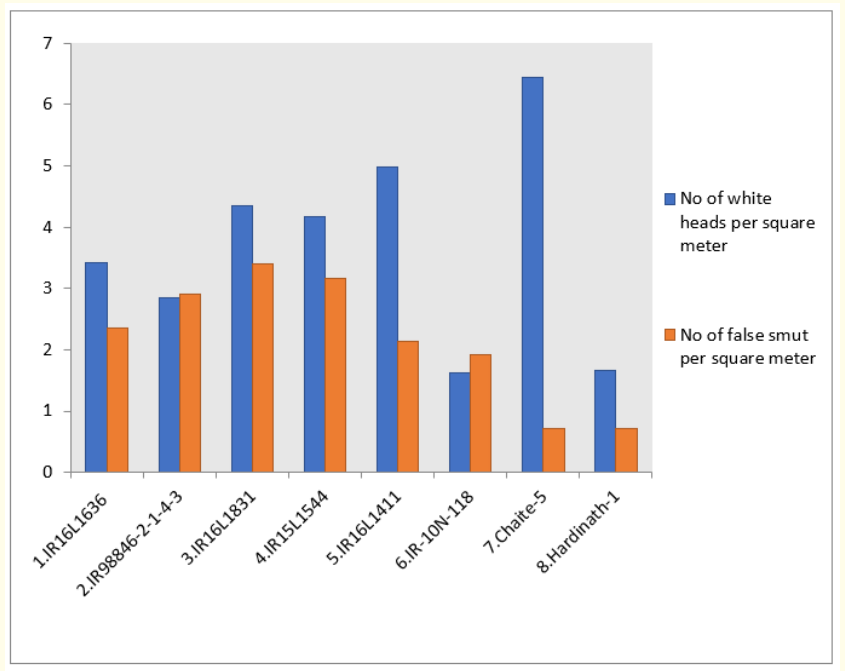

Figure 1 $\backslash$ 2: Borer and false smut infestation per square meter among the different rice genotypes during the spring season of 2020 at Jhapa, Nepal.

\section{Conclusion}

Hardinath-1 was the most productive whereas IR98846-21-2-3 and IR16L1831 were also better in terms of growth and yield attributing characters. Hardinath-1 was the suitable variety for spring season and IR98846-2-1-4-3, IR15L1544, IR16L1411 were also better yielding genotypes for spring season. Similarly, IR16L1636 did not performed well while Chaite-5 was also not much desirable due to the maximum number of sterility and high incidence of borer infestation.

\section{Bibliography}

1. Lu B. "Taxonomy of genus Oryza (Poaceae): historical perception and current status" (1999).

2. Sweeney M and Mccouch S. "The Complex History of the Domestication of Rice" (2007).

3. CDD. "Rice Varietal Mapping in Nepal: Implication for Development and adoption" (2015).

4. Bhawan H. "Inter Provincial Dependency for Agricultural Development Department of Agriculture" (2018).

5. Tripathi B P., et al. "Rice Strategy for Nepal”. Acta Scientific Agriculture 3.2 (2018): 171-180.

6. CDD and ASoN. "Rice Science and Technology in Nepal (A historical, socio-cultural and technical compendium)". (2017): 976.

7. Prasai H K., et al. "Varietal Improvement of Normal Season Irrigated Rice for Eastern Terai Region of Nepal”. International Journal of Applied Sciences and Biotechnology 4.4 (2017): 489497.

8. Joshi B K., et al. "Released and Promising Crop Varieties" (2016).

9. Adhikari B B., et al. "Selection of drought tolerant rice varieties for the western mid hills of Nepal". Journal of the Institute of Agriculture and Animal Science 206 (2018): 195-206.

10. Witcombe J R., et al. "New Rice Varieties for Nepal New Rice Varieties for Nepal : Outcomes of Client- Oriented Breeding or Identified by Participatory Varietal Selection". 2.

11. Tiwari D., et al. "Agro-morphological Variability of Upland Rice Hills Landraces Evaluated at Central Terai Region of Nepal" (2018).

12. MoAD. "Statistical information on nepalese agriculture (2016/17)" (2017). 
13. Joshi K and Witcombe J. "Participatory varietal selection in rice in Nepal in favourable agriculture environments - A comparision of two methods assessed by varietal adoption". Euphytica 127 (2002): 445-458.

14. Abeysiriwardena D S de Z. "Statistical analysis of on-farm yield trials foe testing adaptability of rice". Euphytica 121 (2001): 215-222.

15. Oladosu Y., et al. "Genotypic and Phenotypic Relationship among Yield Components in Rice under Tropical Conditions". Biomed Research International (2018).

16. Adhikari B N., et al. "Genetic variability, heritability, genetic advance, and correlation among yield and yield components of rice (Oryza sativa L.)". Journal of Agriculture and Natural Resources (2018).

17. Poudel A P., et al. "Upland Rice Varietal Trial for the Tars of Western Hills of Nepal” (2014).

18. Shahidullah S., et al. "Tillering Dynamics in aromatic Rice Genotypes" (2009).

19. Saif-Or-Raisheed M., et al. "Causes and Effect Relation of Panicle Traits in Rice (Oryza sativa L.)". Asian Journal of Plant Science 1.2 (2002): 123-125.

20. Howladar M., et al. "Growth and yield performance of ocal T.Aman genotypes in southern region of Bangladesh". Progressive Agriculture 28.2 (2017).

21. Rao AS. "Effect of genotype and environment on seed yield and quality of rice". The Journal of Agricultural Science (2005).

22. Jadhav S., et al. "Genotype by Environment (G*E) interaction study on yield traits in different maturity group of rice". Journal of Crop Science and Biotechnology 22 (2019): 425-449.

23. Matías J., et al. "Evaluation of rice straw yield, fibre composition and collection under mediterranean conditions". Acta Technologica Agriculturae 22.2 (2019): 43-47.

24. Shafique M., et al. "Screening of rice genotypes for resistance to stem borers". Pakistan Journal of Zoology (2020): 135-137.

25. Dwivedi S., et al. "Evaluation of Rice Genotypes for Resistance against False Smut of Rice (Oryza sativa L.) under Middle IGP Bihar". International Journal of Current Microbiology and Applied Science (2017).

26. AITC A I T C. "Krishi Diary". In Government of Nepal (2019).
27. AP Regmi. "Improving the productivity of rice-wheat system through field specific nutrient management in Nepal”. University of the Philippines at Los Banos (2003).

28. Bhandari D., et al. "Policy Review of Paddy Production in Nepal" (2017).

29. CBS C. B. of S. "Statistical pocket book of Nepal". Government of Nepal National Planning Commission (2018).

30. Crop Development Directorate, D. of A. "Rice varietal mapping in Nepal: implication for development and adoption" (2015): 26-27.

31. MoAD. "Rice varietal mapping in Nepal: implication for development and adoption". 90 (2015a).

32. Ono Y., et al. “研 究論文 (Research Article) 11.1 (2015): 307316.

\section{Assets from publication with us}

- Prompt Acknowledgement after receiving the article

- Thorough Double blinded peer review

- Rapid Publication

- Issue of Publication Certificate

- High visibility of your Published work

Website: www.actascientific.com/

Submit Article: www.actascientific.com/submission.php

Email us: editor@actascientific.com

Contact us: +919182824667 